\title{
Upaya Mewujudkan Pemuliaan Profesi Satuan Pengamanan Ditinjau Dari Peraturan Kepolisian Nomor 4 Tahun 2020
}

\author{
Ahmad Khoirun Ni’am*1, Anang Dony Irawan' ${ }^{2}$, Chaeruli Anugrah Dewanto ${ }^{3}$ \\ 1,2 Prodi Ilmu Hukum, Fakultas Hukum, Universitas Muhammadiyah Surabaya, Indonesia \\ ${ }^{3}$ Kantor Wilayah Jawa Timur, Kementerian Hukum dan Hak Asasi Manusia \\ Korespondensi : Jl. Sutorejo No. 59 Surabaya \\ *Korespondensi : anangdonyirawan@fh.um-surabaya.ac.id
}

\section{Info Artikel}

Diajukan: 01-06-2021

Direview: 19-06-2021

Direvisi: 22-06-2021

Diterima: 24-06-2021

DOI: 10.18196/mls.v2i3.11870

\section{Abstrak}

Kapolri telah menetapkan Peraturan Kepolisian Nomor 4 Tahun 2020 Tentang Pengamanan Swakarsa, aturan tersebut untuk mengatur pengamanan-pengamanan swakarsa yang ada di Indonesia salah satunya tenaga satuan pengamanan. Penjabaran Satpam di dalam Perpol Nomor 4 Tahun 2020 Tentang Pengamanan Swakarsa menggolongkannya sebagai Profesi perkerjaan, hal ini merupakan upaya Kapolri dalam mewujudkan pemuliaan profesi Satpam. Akan tetapi peraturan tersebut hanya mengatur bentuk-bentuk pengamanan swakarsa, proses perekrutan, golongan kepangkatan, pelatihan dan kompetensi, secara detail tidak mengatur regulasi khusus tenaga satuan pengamanan yang mengedepankan kesejahteraan Satpam dan kepastian hukum dalam ketenagakerjaan. Tenaga Satuan Pengamanan atau yang biasa kita kenal dengan istilah Satpam termasuk suatu profesi yang kurang dilirik, profesi tersebut merupakan suatu profesi yang tidak diperhitungkan oleh masyarakat yang ada di Indonesia. Seperti yang dilihat dilapangan jika tenaga kerja Satpam digaji rendah, tidak ada jenjang karir, bahkan masa depan tenaga Satpam tidak menjanjikan. Namun apabila jika kita pahami mengenai fungsi serta tugas satpam merupakan suatu pekerjaan yang berat tanggung jawabnya. Berdasarkan permasalahan tersebut tujuan kajian ini secara umum dijalankan dengan tujuan untuk melihat landasan hukum terhadap Satpam dan kedudukan status ketenagakerjaannya. Jenis kajian ini ialah jenis kajian normatif serta metode pendekatan yang dipakai yaitu metode pendekatan yuridis normatif. Hasil kajian ini menunjukkan jika lemahnya sistem hukum yang berlaku di Indonesia terhadap Satpam dalam pemuliaan profesi Satpam terutama terkait perlindungan hukum dan status ketenagakerjaannya. Karena bagi mereka perlindungan hukum sangat dibutuhkan para anggota Satpam.

Kata Kunci : Satuan Pengamanan, Profesi, Ketenagakerjaan, Swakarsa 
profession that is not taken into account by the people in Indonesia. As seen in the field, if the security guard workers are underpaid, there is no career path, even the future for security guards is not promising. However, if we understand the functions and duties of a security guard, it is a job that has a heavy responsibility. Based on these problems, the purpose of this study is generally carried out with the aim of looking at the legal basis for security guards and their employment status. This type of study is a normative study and the approach method used is a normative juridical approach. The results of this study indicate that the weak legal system that applies in Indonesia to security guards in glorifying the security guard profession is mainly related to legal protection and employment status. Because for them legal protection is needed by the Security Guard members

Keywords : Security Unit, Profession, Employment, Self-Reliance

\section{Pendahuluan.}

Pada saat munculnya profesi satpam, keberadaan profesi ini seringkali dipandang remeh oleh berbagai pihak. Alih-alih melakukan penghargaan terhadap dedikasi serta profesi sebagai seorang satpam, akan tetapi di dalam realitanya masih terdapat berbagai lembaga yang menggunakan jasa seorang satpam namun melakukan pembayaran dengan gaji yang di bawah ketetapan upah minimum. Penjaminan berbagai hak dasar tenaga kerja serta penjaminan kesamaan kesempatan dan perlakuan dengan tidak adanya diskriminasi termasuk maksud dari keberadaan perlindungan hukum untuk para tenaga kerja dalam melakukan perwujudan kesejahteraan untuk para pekerja. ${ }^{1}$ Pada Undang-Undang Dasar 1945 menyebutkan bahwa "Tiap-tiap warga Negara berhak atas pekerjaan yang adil tanpa diskriminasi dan mendapat imbalan yang sama dan juga layak dalam hubungan kerja", karena itu tenaga kerja perempuan ataupun tenaga kerja lakilaki tidak dilakukan pembedaan, contoh peluang pekerjaan itu disambut dengan baik oleh berbagai pihak seperti halnya masyarakat supaya bisa mewujudkan kesejahteraan serta kehidupan yang layak untuk seluruh masyarakat. Pada UU sudah dijelaskan jika negara serta berbagai pihak swasta dalam hal ini adalah pengusaha yang memperkerjakan para tenaga kerja memiliki kewajiban dalam memperhatikan berbagai hak para tenaga kerja misalnya yang terdapat pada Undang-Undang Nomor 13 Tahun 2003 yang menjelaskan mengenai ketenagakerjaan. UU tersebut termasuk perwujudan dari peran yang diberikan oleh pemerintah serta pihak penguasa untuk melindungi berbagai tenaga kerja yang terdapat di Negara Indonesia, khususnya pada tenaga kerja satuan pengamanan yang menjalankan pekerjaannya di lembaga usaha swasta sebab dilapangan kurang memperoleh perlindungan kepada berbagai hak yang dimiliki.

Pada dunia usaha sekarang ini adanya persaingan yang begitu kuat, maka dari itu perusahaan-perusahaan akan melakukan penghematan biaya produksi atau efisiensi biaya produksi (Cost of Production). Sistem Outsourcing adalah suatu upaya yang dilakukan oleh perusahaan supaya perusahaan tersebut bisa melakukan penghematan pengeluaran untuk melakukan pembiayaan SDM. Pada aspek ketenagakerjaan, outsourcing di artikan untuk memanfaatkan para pekerja agar bisa melakukan produksi

1 G.Kartasapoetra, R.G.Kartasapoetra, 1986, Hukum Perburuhan di Indonesia Berlandaskan Pancasila,Cetakan ke 1, Bina Aksara, Yogyakarta, hal. 20 
atau melakukan sebuah pekerjaan oleh lembaga usaha melalui lembaga yang menyediakan tenaga kerja atau lembaga yang mengarahkan tenaga kerja. Hal ini bermakna jika lembaga usaha yang secara khusus melakukan pelatihan, melakukan persiapan, melakukan penyediaan, memberikan pekerjaan untuk para pekerja demi kepentingan yang dimiliki oleh lembaga lain. Dasar hukum sistem outsourcing ada di dalam pasal 64 Undang-undang Nomor 13 Tahun 2003 Tentang Ketenagakerjaan.

Profesi Satuan Pengamanan dituntut harus memiliki persiapan pada fisik serta kompetensi yang mumpuni dan sesuai dengan berbagai syarat yang terdapat dalam Standar Kompetensi Kerja Nasional Indonesia bidang usaha jasa pengamanan. Akan tetapi karena berbagai sebab, kurangnya pengawasan dan pelaksanaan komitmen terhadap pengguna jasa pengamanan, komitmen yang dimiliki oleh para pemakai jasa ini masih sangat minim, dan aspek finansial pihak yang memakai jasa pengamanan tidak mencukupi atau bersifat terbatas serta pekerjaan satpam yang seringkali disamakan dengan profesi cleaning service, guru honorer, dan lain sebagainya. Didalam pasal 11 Perkapolri Nomor 24 Tahun 2007, sumber anggota satuan pengamanan didapatkan dari $:^{2}$

a. Pegawai tetap yang dipilih oleh pemimpin suatu organisasi, lembaga usaha ataupun instansi pemerintahan (inhouse security);

b. Lembaga usaha yang menyediakan jasa pengamanan out-source).

BUJP atau "Badan Usaha Jasa Pengamanan" ialah lembaga usaha yang mempunyai bentuk perseroan terbatas, yang menjalankan pekerjaannya di bidang penyedia tenaga kerja satpam, melatih tenaga kerja yang akan bekerja sebagai satpam, pengawalan dalam pendistribusian uang ataupun barang yang berharga, menyediakan konsultasi untuk jasa pengamanan, pengaplikasian alat pengamanan, serta berbagai usaha lain di bidang keamanan. Dalam Undang-undang Cipta Kerja, Kepolisian Republik Indonesia berwenang memberi izin dalam melakukan usaha serta melaksanakan tindakan pengawasan pada lembaga usaha yang bergerak di bidang jasa pengamanan berdasarkan dengan ketentuan yang terdapat pada undang-undang dibidang perizinan. ${ }^{3}$

Pada tahun 2020, Kepolisian Negara Republik Indonesia mengeluarkan Peraturan Kepolisian Negara Republik Indonesia yang selanjutnya di sebut Perpol Nomor 4 Tahun 2020 Tentang Pengamanan Swakarsa atau Pam swakarsa, menurut pasal 1 Perpol No. 4 Tahun 2020 disebutkan bahwa : "Satuan Pengamanan yang selanjutnya disebut Satpam adalah satuan atau kelompok profesi pengemban fungsi kepolisian terbatas non yustisial yang dibentuk melalui perekrutan oleh badan usaha jasa pengamanan atau pengguna jasa satpam untuk melaksanakan pengamanan atau dalam menyelenggarakan keamanan swakarsa di lingkungan kerjanya." (Kepala Kepolisian Negara Republik Indonesia, 2020). ${ }^{4}$

\footnotetext{
${ }^{2}$ Peraturan Kepala Kepolisian Negara Republik Indonesia, 2007 nomer 24 pasal 11

${ }^{3}$ Undang-undang Nomor 11 Tahun 2020 tentang Cipta Kerja pasal 15 huruf $\mathrm{f}$

${ }^{4}$ Peraturan Kepala Kepolisian Negara Republik Indonesia Nomor 4 Tahun tentang Pengamanan Swakarsa
} 
Sebuah profesi umumnya mempunyai asosiasi tenaga kerja, proses sertifikasi kode etik serta suatu lisensi tertentu untuk aspek profesi tersebut, misalnya profesi dalam bidang hukum, tenaga pendidik, keuangan kesehatan dan lainnya. Serta sebuah profesi memiliki Undang-undang khusus atau regulasi yang jelas mengatur profesi tersebut seperti halnya Undang-undang advokad, Undang-undang Kepolisian, Undangundang Kedokteran. Akan tetapi didalam Perpol No. 4 Tahun 2020 mengenai Pamswakarsa tidak memberikan aturan secara detail atau regulasi khusus tenaga satuan pengamanan, Perpol tersebut hanya mengatur bentuk-bentuk Pamswakarsa, proses perekrutan, golongan kepangkatan, pelatihan dan kompetensi, asosiasi anggota satpam, pemberhentian anggota dan secara detail tidak mengatur tentang kesejahteraan satuan pengamanan seperti sistem kerja, hak-hak satuan pengamanan yang di dapatkan, status ketenagakerjaan. Oleh karena itu, perlindungan hukum bagi Satpam sangat perlu dilakukan mengingat kedudukannya sangat lemah.

Satuan Pengamanan ialah bagian dari warga Indonesia yang seharusnya dilakukan perlindungan. Prinsip perlindungan hukum untuk warga negara Indonesia ialah prinsip perlindungan serta pengakuan pada harkat dan martabat masyarakat yang berasal dari Pancasila serta prinsip Negara hukum yang terdapat dalam Pancasila. Sesuai dengan penjelasan latar permasalahan diatas maka di dapatkan permasalahan yang mungkin diperlukan untuk mengetahui regulasi yang mengatur profesi satuan pengamanan dan upaya mewujudkan pemuliaan profesi satuan pengamanan yang selama ini kesejahteraannya jauh dari harapan.

\section{Metode Penelitian.}

Metode yang dipakai pada penulisan ini secara yuridis normatif, yakni penulisan yang didalamnya lebih melakukan penekanan dalam penafsiran hukum positif serta melakukan analisa dengan memakai berbagai sumber literatur, berbagai norma hukum yang tertulis.(Irawan et al., 2021) Dipakai untuk memperoleh kebenaran sesuai dengan logika ilmu hukum pada aspek normatif tentang regulasi pemuliaan profesi tenaga satuan pengamanan yang ditampilkan pada hukum positif dengan memakai suatu pendekatan dalam undang-undang atau Statute Approach, yaitu menganalisa dengan menggunakan bahan hukum yang berupa peraturan perundang-undangan sebagai bahan acuan dasar dalam kajian ini. Dari hasil analisis bahan hukum yang diperoleh, tahap terakhir akan ditarik kesimpulan.

\section{Hasil dan Pembahasan.}

\section{Pengertian Profesi Satpam Menurut Perundang-undangan}

Keberadaan Satpam sebagai profesi yang profesionalisme dan bermartabat merupakan dalam artian menyangkut eksistensinya, baik ditinjau dari berbagai tugas yang diemban, kebijakan, peran serta fungsi untuk melakukan pembantuan Kepolisian dalam menjalankan berbagai tugas kepolisian yang bersifat terbatas. Hal ini bermakna berbagai tugas tersebut berhubungan dengan tugas yang terdapat dalam kepolisian di bidang menegakkan hukum yang mempunyai sifat mencegah di lingkungan tempat 
dalam menjalankan tugasnya, tidak menjalankan penegakan hukum yang mempunyai sifat penindakan ataupun represif, namun apabila jika pelaku berhasil ditangkap di tempat, setiap orang berhak menangkap dan untuk segera melakukan penyerahan barang bukti serta pihak yang menjadi tersangka ke kantor polisi sekitar tempat satpam itu menjalankan pekerjaannya.

Menurut Wardiman Djojonegoro (1998), memberikan penjelasan jika profesionalisme pada sebuah jabatan dilakukan penentuan berdasarkan dengan tiga faktor yang paling pokok, yakni: ${ }^{5}$

1. Mempunyai suatu keahlian yang telah dipersiapkan oleh pihak yang menyediakan keahlian ataupun spesialisasi

2. Mempunyai suatu kompetensi untuk melakukan perbaikan terhadap keterampilan serta suatu keahlian yang dikuasai.

3. Pendapatan yang cukup sebagai imbalan pada kompetensi khusus yang dimiliki.

Sudar Danin sesuai penjelasan yang diungkapkan oleh Howard M.Vollmer dan Donal L Mills, beliau memberikan penjelasan sikap profesi ialah sebuah pekerjaan yang memberikan tuntutan terhadap kompetensi suatu intelektual yang didapatkan dari aktivitas pembelajaran serta latihan yang mempunyai tujuan untuk melakukan penguasaan terhadap suatu keahlian ataupun arahan kepada pihak lain dengan mendapatkan gaji ataupun penghasilan pada jumlah yang telah ditentukan. ${ }^{6}$

Sesuai dengan UU No 14 tahun 2005 bab 1 pasal 4 ayat 4 memberikan penjelasan jika profesional ditampilkan sebagai suatu tindakan ataupun kegiatan yang dilaksanakan oleh suatu individu dan termasuk sumber penghasilan pada kehidupan yang membutuhkan suatu kompetensi, kemampuan serta keahlian yang sesuai dengan standar mutu serta norma dan juga membutuhkan pendidikan mengenai Suatu profesi tersebut.

Tuntutan pada profesionalitas satpam ini dirasa sangat penting serta diperlukan. Hal ini disebabkan didalam industri pengamanan bukan hanya memberi jasa untuk melindungi fisik suatu instansi dari berbagai ancaman serta ketertiban, namun juga sebagai aspek yang memberikan jaminan pada pengendalian ancaman serta permasalahan yang terjadi dari sebuah kegiatan bisnis.

Maka dalam hal ini profesionalisme, kompetensi dan skill anggota Satpam harus diperhatikan agar keamanan dilingkungan penugasan tetap terjaga dari gangguan ancaman keamanan. Direktorat Pembina Potensi Masyarakat Korbinmas Baharkam Polri berikut yang sebut dengan Baharkam Polri, ini yang bertanggung jawab atas pelaksana yang mempunyai tugas untuk melakukan penyusunan serta melakukan pengembangan sistem serta teknik pada aspek membina potensi masyarakat, melakukan pembinaan mengenai keamanan, melakukan pengkoordinasian dalam pengawasan, membina kepolisian tertentu, sertifikasi keahlian profesi satpam sesuai yang tertuang

\footnotetext{
${ }^{5}$ Perihal Profesi Kependidikan, https://datakata.wordpress.com/2015/01/16/perihal-profesi-kependidikan/ (diakses pada tanggal 29 Mei 2021)

${ }^{6}$ https://www.ilmusaudara.com/2015/10/pengertian-profesi-dan-syarat-syarat.html (diakses pada tanggal 31 Mei 2021)
} 
dalam Pasal 1 ayat (19) Perpol No 4 Tahun 2020 yang di dalamnya menjelaskan mengenai Pengamanan Swakarsa.

Satpam merupakan satuan atau kelompok profesi pengemban fungsi Kepolisian terbatas non yustisial yang dibentuk melalui perekrutan oleh BUJP atau pengguna jasa Satpam untuk melaksanakan pengamanan dalam menyelenggarakan keamanan Swakarsa di tempat kerjanya.(Pasal 1 Perpol 4 tahun 2021) Selayaknya sebuah profesi lainnya selain dibidang pengamanan, profesi harus memiliki standar kompetensi khusus dan kode etik. Hal itu diperkuat apa yang disampaikan oleh Korbinmas Baharkam Polri pada sosialisasi Perpol Nomor 4 Tahun 2021 Tentang Pengamanan Swakarsa, Syarat sebuah profesi meliputi:

1. Memiliki kompetensi khusus melalui Diklat

2. Ada organisasi profesi

3. Ada kode etik profesi dan dewan etik

4. Memperoleh kompetensi yang layak

5. Ada pengabdian profesi.

Jika dilihat saat ini Satpam sudah memiliki Standar Kompetensi Kerja Nasional Indonesia (SKKNI), hal itu diatur didalam Keputusan Menteri (Kepmen) Ketenagakerjaan Nomor 259 Tahun 2018 tentang penetapan standar kompetensi kerja nasional Indonesia kategori dibidang jasa satuan pengamanan. Begitu juga yang tertuang dalam Pasal 27 Perpol 4 Tahun 2020, "anggota Satpam harus memiliki kompetensi, meliputi:

a. Kompetensi gada utama;

b. Kompetensi gada madya; dan

c. Kompetensi gada pratama.”(Kepala Kepolisian Negara Republik Indonesia, 2020)

Garda terdepan dalam pengamanan perusahaan merupakan Satpam, maka dari itu sudah sepatutnya satpam mempunyai kemampuan dasar yang bisa dipunyai yakni diawali dari garda Pratama. Ini termasuk suatu pelatihan dasar yang bersifat khusus serta wajib untuk diikuti oleh seluruh calon anggota satpam. Oleh karena itu nanti apabila sudah mempunyai kompetensi serta kemampuan khusus untuk melakukan berbagai tugas kepolisian yang bersifat terbatas di tempat dimana satpam itu bekerja. Pengukuhan anggota Satpam yang telah melakukan pelatihan dan dinyatakan lulus yang di selenggarakan oleh BUJP yang sudah memiliki SIO jasa pelatihan keamanan dari Korbinmas Baharkam Polri akan dikukuhkan oleh Kapolri melalui:

a. Kakorbinmas Baharkam Polri, untuk calon anggota Satpam yang telah lulus Pelatihan Gada Pratama, Pelatihan Gada Madya, dan Pelatihan Gada Utama dari Korbinmas Baharkam Polri dan BUJP yang memiliki SIO jasa pelatihan keamanan; dan

b. Dirbinmas Polda, untuk anggota Satpam yang telah lulus Gada Pratama, dan Gada Madya dari Sekolah Kepolisian Negara dan BUJP yang memiliki SIO jasa pelatihan keamanan. (Pasal 15 Perpol 4 Tahun 2020) 
Etika profesi sebagai satpam ialah ilmu tentang kewajiban moral yang wajib dilaksanakan oleh seseorang yang bekerja sebagai satpam. Kewajiban tersebut mempunyai penonton yang terdapat pada berbagai prinsip penuntun satpam, mencakup:

1. Kami anggota satuan pengamanan, memegang teguh disiplin, patuh dan taat pada pimpinan, jujur dan bertanggung jawab

2. Kami anggota satuan pengamanan, senantiasa menjaga kehormatan diri dan menjunjung tinggi kehormatan satuan pengamanan

3. Kami anggota satuan pengamanan, senantiasa waspada dalam melaksanakan tugas sebagai pengaman dan penertib di lingkungan kerja

4. Kami anggota satuan pengamanan, senantiasa bersikap terbuka, tidak menganggap remeh sesuatu yang terjadi di lingkungan kerja

5. Kami anggota satuan pengamanan, adalah petugas yang tangguh dan senantiasa bersikap etis dalam penegakan peraturan. ${ }^{7}$ (Jaya, 2016)

Berikut ini adalah beberapa kode etik satuan pengaman:

1. Mempunyai keimanan serta ketakwaan kepada Tuhan yang maha esa

2. Menjunjung tinggi UUD 1945 serta berbagai nilai yang terdapat pada Pancasila.

3. Melakukan penjagaan terhadap ketertiban umum dengan rasa tanggung jawab.

4. Selalu berjaga-jaga terhadap berbagai kemungkinan adanya ancaman ataupun gangguan.

5. Selalu menjalankan pengertian luhur sesuai dengan hati nurani. ${ }^{8}$ (Jaya, 2016)

Prof. Dr. R. Soebekti, S.H. memberikan penjelasan pada karyanya yang mempunyai judul "Etika bantuan hukum" kode etik sebuah profesi yang berwujud beberapa norma yang wajib diperhatikan oleh berbagai pihak yang melakukan tugas dalam profesi itu. ${ }^{9}$ Kode etik sebuah profesi ialah berbagai norma yang wajib dipahami oleh berbagai profesi dalam menjalankan tugas profesi serta pada kehidupan di lingkungan masyarakat.

Maka dari itu syarat sebuah profesi memiliki kode etik profesi memang sangat penting, terlebih terhadap profesi Satpam, dikarenakan penjabaran tentang Satpam didalam Perpol Nomor 4 tahun 2020 tentang Pengamanan Swakarsa, menyebutkan Satpam bukan lagi disebut sebuah pekerjaan biasa melainkan sebuah profesi yang mengemban tugas dan kewenangan kepolisian terbatas di wilayah kerjanya.

Adanya Asosiasi Profesi Satpam adalah faktor penting dalam sebuah syarat profesi. Dikarenakan Asosiasi tersebut dapat menjadi tempat yang nyata untuk melakukan penampungan aspirasi para pekerja, bisa memperjuangkan berbagai hak yang dimiliki sesuai dengan ketetapan perundang-undangan di Indonesia. Aturan Asosiasi Satpam sendiri sebenarnya sudah diatur didalam Pasal 32 Perpol Nomor 4 tahun 2020, yang berbunyi:

1. Anggota satpam bisa menciptakan asosiasi anggota satpam

\footnotetext{
${ }^{7}$ Polda Metro Jaya, Buku saku satuan pengamanan.(PT.Universal Security Indonesia, 2016), Hal 5.

${ }^{8}$ Polda Metro Jaya, buku, Buku saku satuan pengamanan.(PT.Universal Security Indonesia, 2016), Hal 6.

${ }^{9}$ https://www.dosenpendidikan.co.id/kode-etik/ (diakses pada tanggal 29 Mei 2021)
} 
2. Asosiasi dari anggota satpam seperti yang terdapat pada ayat 1 termasuk himpunan yang didalamnya terdapat aspirasi serta kepentingan yang dimiliki oleh para anggota satpam

3. Asosiasi yang terdapat pada pasal 1 wajib dilakukan registrasi dalam korbinmas baharkam polri dengan melalui melalui Dirbinpotmas Korbinmas Baharkam Polri.

4. Asosiasi seperti yang terdapat pada ayat 3 wajib melakukan penyusunan kode etik

5. Pada penyusunan kode etik, asosiasi melakukan pembentukan tim formatur yang anggotanya mencakup perwakilan asosiasi serta polri

6. Kode etik yang telah dilakukan penyusunan oleh asosiasi akan disampaikan pada Kapolri untuk bisa disahkan.(Kepala Kepolisian Negara Republik Indonesia, 2020)

Terdapat aturan yang mengatur tentang Asosiasi Anggota Satpam di dalam Perpol tersebut merupakan bukti upaya Kapolri dalam mewujudkan pemuliaan profesi satuan pengamanan, dikarenakan anggota satpam mempunyai kebebasan dalam beraspirasi.

Perubahan warna seragam Satpam yang mempunyai kemiripan warna dengan seragam dinas Polri dan adanya golongan kepangkatan diatur juga didalam Perpol Nomor 4 tentang Pengamanan Swakarsa, yang sebelumnya tentang seragam dinas Satpam diatur didalam Perkap Nomor 24 tahun 2007. Seperti yang kita lihat di lapangan saat ini, Satpam mulai melakukan peralihan seragam lama ke seragam baru, yang sebelumnya menggunakan warna putih dan biru sekarang menggunakan warna coklat yang mirip dengan seragam Polri dengan warna lebih cerah $20 \%$ degradasi dari seragam Polri. Pergantian warna seragam dinas Satpam Menurut Brigjen. Pol. Edy Murbowo, S.I.K., M.Si (Dirbinpotmas Korbinmas Baharkam Polri) “...kalau dilihat saat ini di kalangan masyarakat Satpam menjadi bahan perundungan, selaku pembina Satpam kita berbicara dengan asosiasi Satpam, kita bersepakat untuk mengangkat harkat dan martabat Satpam, jadi di balik ditetapkannya Perpol Nomor 4 Tahun 2020 ada Pemuliaan Profesi Satpam". ${ }^{10}$

Melihat upaya Kapolri untuk merubah warna seragam dinas Satpam yang mirip dengan seragam dinas polri diharap bisa menjalin hubungan emosional dengan polri serta satpam, menciptakan kebanggaan pada dirasakan sebagai pihak yang mempunyai fungsi kepolisian yang bersifat, memberikan kemuliaan pada profesi sebagai satpam, memberikan tambahan pagelaran fungsi kepolisian yang ada di dukungan masyarakat.

\section{Landasan Hukum Satpam dan BUJP dalam Mewujudkan Pemuliaan Profesi Satpam}

Di Indonesia, sesuai dengan UUD 1945 serta Pancasila jika semua warga negara berhak untuk mendapatkan perlindungan hukum. Pancasila ialah Suatu ideologi yang dipegang teguh oleh seluruh masyarakat Indonesia, hal ini berarti jika pada tindakan berpikir serta bertindak masyarakat Indonesia harus diberikan pengaruh oleh ideologi Pancasila, serta berbagai nilai yang terdapat pada Pancasila. ${ }^{11}$ Lembaga Satpam muncul

10 Sosialisasi Perpol No 4 tahun 2020 Bersama Polri, Abujapi, Apsi, Host Sabena Rangkuti, https://www.youtube.com/watch?v=Yam1wpBJyzY (diakses tanggal 20 Mei 2021)

11 Achmad Hariri, Rekontruksi Ideologi Pancasila Sebagai Sistem Ekonomi Dalam Perspektif Welfare State, Jurnal Hukum Replik, Vol. 7 No.1, Maret 2019. 
di Indonesia pada tanggal 30 Desember 1980 yang didasari karena adanya kebijakan kepala kepolisian Negara Indonesia no SKEP/126/XII/1980 mengenai bentuk pembinaan satuan pengaman pada kala itu di jabat Jendral Polisi (Purn) Prof. DR. Awaloedin Djamin dikukuhkan sebagai bapak Satpam. ${ }^{12}$ Di dalam pasal 3 Undangundang Republik Indonesia Nomor 2 Tahun 2002 Tentang Polri memberikan penjelasan jika pihak yang mengemban fungsi kepolisian ialah polri yang didukung oleh satuan kepolisian khusus, penyidik pegawai negeri sipil serta berbagai bentuk pengaman Swakarsa. Yang disebut sebagai untuk pengamanan Swakarsa ialah sebuah bentuk pengamanan yang disediakan karena adanya kemauan, kesadaran serta kepentingan yang dimiliki oleh masyarakat yang setelah itu mendapatkan pengukuhan yang dilakukan oleh pihak polri misalnya satuan pengamanan. Berbagai bentuk pengamanan Swakarsa mempunyai kebijakan kepolisian yang bersifat terbatas pada lingkungan kuasa sekitar, mencakup lingkungan pemukiman, lingkungan pendidikan serta lingkungan kerja. Namun pada tahun 2020 kebijakan politik yang berhubungan dengan izin jasa pengamanan dilakukan revisi pada pasal 7 UU cipta kerja tahun 2020, dalam pasal itu memberikan perubahan terhadap kebijakan pada pasal 15 UU No 2 tahun 2002 mengenai Kepolisian Republik Indonesia, dalam pasal 15 huruf f saat ini pada UU cipta kerja, polri mempunyai kewenangan untuk memberi perizinan berusaha dalam mendirikan BUJP. Berikut adalah bunyi Pasal 75 Undang-Undang Cipta Kerja yang merevisi pasal 15 Undang-undang Polri : "Kepolisian Negara Republik Indonesia sesuai dengan ketentuan peraturan perundang-undangan berwenang:

a. Memberikan izin dan mengawasi kegiatan keramaian umum dan kegiatan masyarakat lainnya;

b. Menyelenggarakan registrasi dan identifikasi kendaraan bermotor;

c. Memberikan surat izin dan mengemudi kendaraan bermotor;

d. Menerima pemberitahuan tentang kegiatan politik;

e. Memberikan izin dan melakukan pengawasan senjata api, bahkan peledak, dan senjata tajam;

f. Memberikan Perizinan Berusaha dan melakukan pengawasan terhadap badan usaha di bidang jasa pengamanan sesuai dengan ketentuan perundang-undangan di bidang Perizinan Berusaha;

g. Memberikan petunjuk, mendidik, melatih aparat kepolisian khusus dan petugas pengamanan swakarsa dalam bidang teknik kepolisian;

h. Melakukan kerja sama dengan kepolisian negara lain dalam menyidik dan memberantas kejahatan Internasional;

i. Melakukan pengawasan fungsional kepolisian terhadap orang asing yang berada di wilayah Indonesia dengan koordinasi instansi terkait;

j. Mewakili Pemerintah Republik Indonesia dalam organisasi kepolisian Internasional; dan

\footnotetext{
${ }^{12}$ H. Arkian Luis, Satpam Indonesia, Jakarta, Elex Media Komputindo, 2019
} 
k. Melaksanakan kewenangan lain yang termasuk dalam lingkup tugas kepolisian.”(Goverment of Indonesia, 2020)

Dengan adanya perubahan kewenangan tersebut maka polri bisa memberi izin untuk melakukan usaha kepada BUJP di bidang jasa penyedia pengamanan yang dahulunya dirubah kewenangannya hanya untuk memberi perizinan operasional serta menjalankan pengawasan pada BUJP. Hal tersebut sesuai dengan yang terdapat pada pasal 15 ayat 2 huruf F UU No 2 tahun 2002 mengenai kepolisian Republik Indonesia.

Kemudian pada tahun 2018, Menteri Koordinator Perekonomian Indonesia telah menetapkan serta diberlakukan aturan yang dikeluarkan oleh pemerintah no 24 tahun 2018 mengenai layanan izin berusaha yang diintegrasikan secara elektronik. Dalam tindakannya kebijakan penerbitan izin untuk melakukan usaha seperti yang dijelaskan pada PP tersebut, seperti halnya pada penerbitan Surat Perizinan Operasional (SIO) Badan Usaha Jasa Pengamanan (BUJP). Pengeluaran surat izin Untuk melakukan usaha dilaksanakan dengan melalui sistem online yang bertujuan untuk melakukan akomodir seluruh izin melakukan usaha lintas kementerian serta lintas pusat wilayah pada sebuah sistem. Pelaku usaha dapat mengurus perizinan usahanya dengan melengkapi semua persyaratan-persyaratan yang ada di aplikasi OSS, dengan sistem seperti ini pelaku usaha dapat dipermudah segala urusan perizinan berusahanya, bisa dilakukan dengan menggunakan aplikasi tersebut serta pihak pengusaha bisa memperoleh identitas elektronik yang dikenal dengan istilah Nomor Induk Berusaha (NIB). Jika pelaku usaha dapat memenuhi persyaratan yang ada di aplikasi OSS, maka pengusaha itu akan memperoleh izin untuk mendirikan usaha.

Jika berbagai komitmen lainnya yang ditetapkan dalam izin usaha sudah bisa dipenuhi oleh pihak pengusaha, maka pihak pengusaha akan memperoleh izin operasional. Akan tetapi pengusaha masih wajib melakukan pelengkapan terhadap berbagai syarat lainnya sebelum melakukan permohonan untuk memperoleh izin operasional lain sesuai dengan aktivitas usaha serta produk yang kita kenal dengan istilah surat izin operasional BUJP yang dikeluarkan oleh Kapolri, sedangkan BUJP yang telah mendapatkan SIO jasa yang menyediakan tenaga pengamanan serta jasa latihan keamanan yang berasal dari Kapolri bermakna telah mempunyai hak untuk melakukan upaya jasa keamanan. Sesuai yang tertuang didalam Pasal 8 Peraturan Kepolisian Republik Indonesia Nomor 4 Tahun 2020 Mengenai Pam Swakarsa, untuk mendapatkan SIO jasa penyedia tenaga pengamanan, BUJP wajib memenuhi berbagai syarat sebagai berikut:

a. Surat rekomendasi yang diberikan oleh Polda setempat

b. Syarat mendirikan lembaga usaha yang berbentuk PT yang sudah dicantumkan layanan pengamanan sebagai suatu aspek usahanya

c. Mempunyai struktur organisasi lembaga usaha

d. Melakukan pelampiran riwayat hidup pemimpin, staf, $t$ tenaga ahli dari lembaga BUJP

e. Pemimpin serta tenaga hari mempunyai ijazah Gada Utama 
f. Surat bukti domisili lembaga usaha dari pemerintahan setempat serta di dalamnya dicantumkan layanan keamanan sebagai suatu aspek usahanya

g. Melakukan pelampiran fotocopy NPWP.

h. Melakukan pelampiran bukti laporan pembayaran pajak yang dilakukan setiap tahunnya apabila SIO dilakukan perpanjangan

i. Surat pendirian usaha yang berasal dari dinas industri serta perdagangan

j. Surat izin Untuk melakukan usaha yang berasal dari harga koordinasi penanaman modal serta instansi yang berkaitan.

k. Melakukan penampilan fotocopy dokumen imigrasi yang sah untuk tenaga kerja yang berasal dari luar negeri

1. Melakukan pengambilan surat keterangan sebagai anggota asosiasi yang menjalankan tugasnya di bidang keamanan yang didaftarkan di polri

m. Melakukan pelampiran KTP pemimpin lembaga usaha

n. Melakukan pelampiran sertifikasi serta bukti telah melakukan pembayaran iuran dari lembaga penyelenggara jaminan sosial ketenagakerjaan

Agar memperoleh SIO jasa latihan keamanan, BUJP wajib memenuhi berbagai persyaratan seperti berikut:

a. Adanya surat rekomendasi yang berasal dari Polda

b. Surat pendirian lembaga usaha yang berwujud PT yang sudah tercantum jasa pengamanan selaku salah satu aspek usaha yang ada

c. Mempunyai struktur organisasi

d. Di dalamnya dilampirkan riwayat hidup pemimpin, staf serta tenaga ahli.

e. Mempunyai berbagai fasilitas serta sarana prasarana jasa pelatihan.

f. Melaksanakan pelampiran riwayat hidup pihak instruktur pelatihan.

g. Surat pernyataan domisili lembaga usaha dari pemerintah setempat serta di dalamnya dicantumkan jasa pengamanan selaku aspek usahanya

h. Melakukan pelampiran fotocopy NPWP

i. Melakukan pelampiran laporan pajak setiap tahunnya apabila SIO kelakuan perpanjangan.

j. Tanda pendaftaran perusahaan yang berasal dari dinas perdagangan serta perindustrian setempat

k. Surat perizinan menjalankan usaha akan lembaga koordinasi lembaga koordinasi penanaman modal serta instansi yang berkaitan

1. Melakukan pelampiran fotokopi KTP

Dengan diterbitkannya aturan kepolisian No 4 tahun 2020 mengenai Pam Swakarsa, diharapkan bisa menciptakan ketertiban pada negara yang mencakup pemeliharaan keamanan serta ketertiban para warga, ketertiban serta penegakan hukum, terlaksananya perlindungan, mengayomi serta memberi layanan untuk masyarakat, perlu mengikutsertakan dan melakukan peningkatan kemampuan dalam pengamanan swakarsa untuk melakukan pembantuan berbagai tugas dari polisi Negara republik Indonesia. Didalam Pasal 3 Perpol Nomor 04 Tahun 2020 Tentang Pam Swakarsa, Pam Swakarsa dibentuk untuk bertujuan melakukan penjagaan terhadap ketertiban serta 
keamanan di lingkungan Swakarsa untuk melakukan pencegahan munculnya ancaman serta gangguan. Berikut ini adalah berbagai bentuk dari Pam Swakarsa, meliputi satpam, satkamling, pam swakarsa yang bersumber dari pranata sosial ataupun kearifan lokal misalnya pecalang di bali, kelompok yang menyadari akan pentingnya ketertiban serta keamanan.

Sebagaimana yang tertuang didalam Pasal 1 ayat (4) Perpol Nomor 4 tahun 2020 mengenai Pam Swakarsa, Anggota Satpam adalah petugas pengamanan swakarsa yang direkrut, dilatih, memiliki kartu tanda anggota dan status ketenagakerjaan sesuai dengan ketentuan peraturan perundang-undangan.(Kepala Kepolisian Negara Republik Indonesia, 4/2020) Akan tetapi kenyataan di lapangan terdapat berbagai satuan yang tidak berposisi sebagai polsus, PPNS ataupun Pam Swakarsa, melaksanakan berbagai tugas pokok sebagaimana fungsi dari pihak kepolisian serta melakukan tindakan kepolisian, misalnya melakukan pengamanan di DPR (Pamdal), melakukan pengamanan di bandara (Avsec), melakukan pengamanan di berbagai tempat lainnya.

Dengan adanya realita tersebut maka dasar hukum pada tata kelola pegawai keamanan yang mempunyai fungsi kepolisian yang terbatas, sekiranya masih perlu dilakukan sosialisasi di lingkungan aparat pemerintah ataupun di lingkungan masyarakat, terutama para pihak pemakai jasa petugas pengamanan yang melakukan fungsi kepolisian serta tindakan kepolisian. Bahkan di berbagai wilayah di Indonesia masih terdapat masyarakat yang memakai fungsi pengamanan/keamanan yang dilakukan beragam lapisan masyarakat yang ada di negara Indonesia, usaha perorangan ataupun kelompok, sebab fungsi pengamanan tersebut dapat dilakukan oleh usaha mereka sendiri, terlepas dari apakah perilaku tersebut legal ataupun bukan, semua melakukan pekerjaan serta memenuhi tugasnya. Untuk kegiatan misalnya fungsi kepolisian ataupun tindakan kepolisian, terdapat anggota kelompok masyarakat yang dijadikan sebagai pengawal pribadi serta terdapat juga yang melaksanakan tindakan penyelidikan berdasarkan perintah pemakai. Kedua modus kegiatan ini pada dasarnya tidak terawasi dan tidak terawasi dalam aturan perundang-undangan yang ada, sehingga jika seseorang melakukan hal itu, berarti ia secara ilegal melakukan fungsi pengamanan/keamanan kepolisian.

Namun anggota Satpam masih banyak yang ada pada kesenjangan, dalam makna tugas yang dimilikinya lebih berat daripada kompensasi yang didapatkan, realita tersebut semakin diperkuat oleh lembaga INDEF, Ennya Sri Hartati peneliti dari INDEF memaparkan Indonesia belum dapat melakukan penyelesaian permasalahan pekerja ataupun tenaga kerja padahal negara ini telah merdeka selama 70 tahun. ${ }^{13}$ Didalam dunia Industri Satpam, saat ini perekrutan tenaga satuan pengamanan lebih sering memakai tenaga untuk mengamankan yang bersumber dari luar lembaga itu atau biasa dikenal dengan sebutan outsourcing. ${ }^{14}$ Outsourcing dari kajian ekonomi yang

13 http://www.tribunnews.com/nasional/2017/04/30/hanya-indonesia-yang-terus-berkutat-masalah-upahburuh

$\underline{{ }^{14} \text { https://security.astacademy.or.id/news/19-sejarah-satpam-satuan-pengamanan }}$

November 2018, diakses 26 Mei 2021. 
mempunyai tujuan untuk mencapai keefisienan pekerjaan apabila dibanding dengan memakai in house manufacturing. ${ }^{15}$ (Wijayanti, 2012) Di Indonesia usaha bidang pengamanan adapun lembaga yang menyediakan jasa pengamanan, Sama halnya dengan outsourcing, sehingga BUJP sama diartikan dengan penyedia jasa tenaga kerja lainnya. Dalam sistem outsourcing, yang diketahui jika tindakan jasa penunjang ataupun tindakan yang tidak berkaitan secara langsung dengan kegiatan produksi ialah aktivitas yang hubungannya di luar dari suatu upaya atau disebut sebagai core business sebuah lembaga usaha dan aktivitas tersebut salah satunya adalah upaya di bidang tenaga pengamanan. Tujuan dilakukannya pengaturan outsourcing ialah untuk memberi perlindungan secara hukum untuk para pihak yang tengah melaksanakan kegiatan hubungan pekerjaan yang menggunakan sistem outsourcing. ${ }^{16}$ Perilaku perusahaan penerima pekerjaan memberikan upah rendah kepada pekerja outsourcing ini menjadi titik sentral kelemahan legalisasi sistem outsourcing.(Nursalim \& Suryono, 2021) ${ }^{17}$

Hubungan pekerjaan yang dijalankan dengan cara outsourcing menyangkut 3 pihak yaitu perusahaan pengguna, lembaga penyedia layanan serta tenaga kerja. ${ }^{18}$ Pada pasal 65 UU No 13 tahun 2003 yang di dalam mengenal memberikan penjelasan mengenai ketenagakerjaan yang memberikan pengaturan mengenai suatu pekerjaan yang bisa dilimpahkan pada perusahaan lainnya ataupun bisa juga dikenal sebagai sebuah pembatasan dari aktivitas outsourcing misalnya yang ada dalam pasal 65 ayat 1 hingga ayat 9. Dan dalam pasal 66 ayat (1) UU nomor 13 Tahun 2003 mengenai Ketenagakerjaan memberikan keterangan lebih rinci yaitu "Pada pekerjaan yang berhubungan dengan kegiatan usaha pokok atau kegiatan yang berhubungan langsung dengan proses produksi pengusaha hanya diperbolehkan memperkerjakan pekerja/buruh dengan Perjanjian Kerja Waktu Tertentu (PKWT) dan/atau Perjanjian Kerja Waktu Tidak Tertentu (PKWTT)." Aturan PKWT sesuai dengan (pasal 65/7 jo pasal 59 UU 13/2003), Yakni untuk suatu pekerjaan yang sesuai dengan jenis dan sifat ataupun kegiatan dalam pekerjaan agar bisa dilakukan penyelesaian dalam waktu tertentu, yakni:

a. Pekerjaan yang sekali selesai atau yang sementara sifatnya;

b. Pekerjaan yang diperkirakan penyelesaiannya dalam waktu yang tidak terlalu lama dan paling lama 3 tahun;

c. Suatu pekerjaan yang mempunyai sifat musiman.

d. Suatu pekerjaan yang berkaitan dengan barang baru, aktivitas baru serta barang tambahan yang pada saat ini masih berada pada uji coba

e. Tidak bisa diadakan untuk suatu pekerjaan yang mempunyai sifat tetap

\footnotetext{
15 Wijayanti, A. (2012). Menuju Sistem Hukum Perburuhan Indonesia Yang Berkeadilan. Arena Hukum, 5(3), 210-217

16 Asri Wijayanti, Reformasi Pengaturan Outsourscing, Jurnal Hukum UPH Surabaya Law Review' Volume XII.[41]

17 Nursalim, C. R. P., \& Suryono, L. J. (2021). Perlindungan Hukum Tenaga Kerja pada Perjanjian Kerja Outsourcing. Media of Law and Sharia, 2(1), 47-62. https://doi.org/10.18196/mls.v2i1.11478

${ }^{18}$ Anang Dony Irawan, Status Hukum Outsourcing Pasca Putusan Mahkamah Konstitusi Perkara Nomor 27/PUU-IX/2011, Arena Hukum, Vol.12, No 2 (2019).
} 
f. Suatu pekerjaan pada kurun waktu 2 tahun serta dapat dilakukan perpanjangan hingga 1 tahun.

g. Pembaruan bisa dilaksanakan sesudah 30 hari selesainya PKWT maksimum 2 tahun.

h. Syarat lainnya sesuai dengan Keputusan Menteri atau Kepmen (Pasal 59/8 UU 13/2003).

Sedangkan PKWT "Perjanjian Kerja Waktu Tertentu" menurut penjabaran didalam Peraturan Pemerintah Nomor 35 Tahun 2021, PKWT iyalah suatu perjanjian kerja yang dilakukan oleh pihak yang memberikan pekerjaan dengan pihak pekerja untuk melakukan hubungan pekerjaan pada beberapa periode atau pun untuk melakukan suatu pekerjaan. PKWT itu didasari pada jangka waktu dibuat paling lama 5 tahun atau selesainya suatu pekerjaan. PKWT berdasarkan atas jangka waktu dibuat untuk pekerjaan tertentu yakni:

a. Suatu pekerjaan yang dinilai dalam penyelesaiannya bisa dilakukan dalam waktu yang relatif singkat.

b. Suatu pekerjaan yang mempunyai sifat musiman.

c. Suatu pekerjaan yang berkaitan dengan barang baru, aktivitas baru ataupun barang tambahan yang yang masih berada pada tahap uji coba.

PKWT sesuai dengan waktu selesai pekerjaan, dibuat untuk suatu pekerjaan tertentu yakni:

a. Suatu pekerjaan yang bisa diselesaikan dalam waktu sekali kerja

b. Suatu pekerjaan yang mempunyai sifat sementara. (Pasal 5 PP Nomor 35 Tahun 2021)

Profesi sebagai satpam disamakan dengan berbagai pekerjaan untuk suatu waktu tertentu yakni sebuah pekerjaan yang dalam waktu satu kali ataupun pekerjaan yang bersifat sementara, seperti yang telah diatur pada Pasal 59 ayat (1) UU Nomor 13 Tahun 2003 dan PP Nomor 35 Tahun 2021. Hal ini membuat para satpam pindah dari suatu BUJP ke BUJP yang lainnya sesudah berakhirnya perjanjian kerja.

Pasal 1 Peraturan Pemerintah Nomor 35 Tahun 2021, menjabarkan Jika hubungan kerja ialah suatu hubungan yang terjadi diantara pihak pengusaha dengan pihak pekerja sesuai dengan perjanjian yang telah dibuat yang di dalamnya terdapat berbagai unsur mengenai pekerjaan, gaji serta perintah. Oleh karena itu dari perjanjian tersebut yang dilakukan oleh pihak tenaga kerja dengan pihak pengusaha terdapat konsekuensinya, pada pihak tenaga kerja mendapatkan gaji dari pihak pengusaha serta tenaga kerja tersebut mempunyai kewajiban untuk menjalankan kegiatan untuk pihak pengusaha, sehingga memenuhi unsur hubungan kerja.

Dengan terdapatnya gaji, pekerjaan serta perintah yang sesuai dengan kebijakan yang berlaku sehingga pihak yang bekerja sebagai pengaman dalam status ketenagakerjaannya ialah tenaga kerja yang wajib mengikuti aturan yang terdapat pada UU No 13 tahun 2003 mengenai Ketenagakerjaan serta Peraturan Pemerintah Nomor 35 Tahun 2021. 


\section{Perlindungan Hukum Profesi Satuan Pengamanan}

Perlindungan terhadap hukum memiliki arti sebagai "perlindungan dengan menggunakan sarana hukum atau perlindungan yang diberikan oleh hukum, ditujukan kepada perlindungan terhadap kepentingan-kepentingan tertentu, yaitu dengan cara menjadikan kepentingan yang perlu dilindungi tersebut ke dalam sebuah hak hukum". ${ }^{19}$ Dimasyarakat, terdapat perbedaan antara aturan hukum dan pelaksanaanya. ${ }^{20}$ Perlindungan hukum dibutuhkan bagi kelompok yang rentan. ${ }^{21}$ Didalam hukum ketenagakerjaan, terdapat dua pihak yang mempunyai kepentingan yang berbeda, yakni pihak yang memberikan pekerjaan serta pihak pekerja. Negara wajib membuat peraturan hukum yang menciptakan persamaan hak buruh serta pihak yang memberi pekerjaan. ${ }^{22}$ Begitu juga dengan keberadaan tenaga kerja sebagai seorang manusia memiliki hak sama dengan manusia lainnya dalam hal mendapatkan dan melakukan pekerjaan serta menerima imbalan secara adil. ${ }^{23}$

Mengenai hal ketenagakerjaan, terdapat suatu unsur yang tidak dapat terlepas dari hal tersebut, salah satunya yakni upah. ${ }^{24}$ Apabila kita menengok pada penugasan profesi Satpam pada berbagai tempat kerja. Profesi ini akan mempunyai ancaman atau Resiko yang mempunyai kadar ringan, menengah hingga berat, seperti yang ada dalam UU No 2 tahun 2002 mengenai Polri pasal 3, Satpam mempunyai tanggung jawab yang penting sama halnya dengan berbagai pekerjaan lain, Satpam mempunyai berbagai tugas seperti halnya melakukan penjagaan supaya tercipta ketertiban, memberi keamanan serta menciptakan rasa nyaman dan juga memberikan layanan untuk para karyawan, tamu serta para pengunjung di lingkungan tempat kerjanya, hal itu juga harus sebanding atau adil dalam imbalan/pengupahan yang diberi pengguna tenaga Satpam. Pasal 28 D ayat (2) UUD 1945 yakni "Setiap orang berhak untuk bekerja serta mendapat imbalan dan perlakuan yang adil dan layak dalam hubungan kerja. Penakrifan upah yang adil dan layak dalam suatu hubungan kerja adalah penghasilan yang layak bagi kemanusiaan" (Pasal 88 ayat (1) UU No 13 Tahun 2003). Penjelasan yang berhubungan dengan gaji dijelaskan sebagai: hak para tenaga kerja yang didapatkan serta dilakukan pernyataan dalam wujud uang sebagai bentuk imbalan dari pihak yang mempekerjakan atau pihak yang memberi pekerjaan kepada para pekerja yang telah ditentukan serta dilakukan pembayaran sesuai dengan perjanjian yang telah dibuat, perjanjian ataupun aturan yang terdapat perundang-undangan seperti halnya memberikan tunjangan untuk para pekerja serta para pihak keluarganya pada sebuah

\footnotetext{
19 Asri Wijayanti, Reformasi Pengaturan Outsourscing, Jurnal Hukum UPH Surabaya Law Review' Volume XII.[41]

20 Asri Wijayanti, (2017) Rights to the freedom of trade unions in the constitution and its implementastion, International journal off Applied Business in Economic Research Vol. 15, No.7.

21 Asri Wijayanti, Recognition And Protection of Religious Sects In Indonesia, Man in India, http://serialsjournals.com/serialjournalmanager/pdf/1507180504.pdf

${ }^{22}$ Asri Wijayanti, Hak Berserikat Buruh di Indonesia, Disertasi, PPS Universitas Airlangga, 2011, hal. 18

23 P.Murung, K., \& Buhoy,(2013). Perlindungan Hukum Bagi Pekerja ( Hambatan dan Upaya Sistem Perjanjian Kerja Waktu Tertentu. 308-335. Arena Hukum, Vol 6, No 3.

${ }^{24}$ Aksin N, (2018), Upah Dan Tenaga Kerja (Hukum Ketenagakerjaan Dalam Islam), Jurnal MetaYuridis, Vol 1.No 2.
} 
pekerjaan ataupun jasa yang sudah dilaksanakan (Pasal 1 angka 30 UU Nomor 13 Tahun 2003). Aturan ini tidak dilakukan penjelasan secara rinci pada aturan pihak pelaksana. Namun jumlah gaji minimal yang didapatkan oleh para pekerja sesuai dengan kebutuhan hidupnya, Pasal 1 angka 1 Permenakertrans No 13 Tahun 2012 yang di dalamnya memberikan penjelasan mengenai komponen serta pelaksanaan tahap mencapai keperluan hidup yang layak, mendefinisikan KHL ialah standar keperluan suatu individu ataupun seorang tenaga kerja yang lajang untuk memenuhi kebutuhan hidupnya secara layak dalam waktu 1 bulan.

Adanya potensi dilanggarnya teori hukum mengenai gaji yang sesuai, sesuai yang tertuang didalam Pasal 3 Konvensi ILO Nomor 131: berbagai unsur yang wajib dilakukan pertimbangan dalam melakukan penentuan rasio gaji minimum, sejauh mungkin serta sesuai dengan keadaan serta prakteknya, seharusnya bisa mencukupi berbagai hal seperti berikut:

a. Kebutuhan para tenaga kerja serta para keluarganya, melakukan pertimbangan rasio gaji umum di wilayah yang bersangkutan, biaya kehidupan, jaminan terhadap kesehatan, salsa standar hidup yang sesuai dengan berbagai kelompok sosial lain.

b. Berbagai faktor ekonomi, seperti halnya beberapa keperluan pembangunan ekonomi, rasio produktivitas serta keperluan untuk mencapai dan juga melakukan pemertahanan rasio lapangan kerja yang besar (Upah, 1970) $)^{25}$

Jika sebuah peraturan hukum perlawanan dengan teori yang terdapat pada hukum yang telah dilakukan pengakuan oleh sifat universal yang dimilikinya, sehingga terdapat kemungkinan yang besar akan munculnya pelanggaran filsafatnya.(Wijayanti, $2012)^{26}$ Tindakan pemberian gaji yang adil untuk para pegawai belum bisa dilakukan, sebab terdapat kekeliruan aturan mengenai gaji minimum pada tatanan dogmatika hukum. Filsafat hukum serta teori hukum menyebabkan kesalahan suatu tuntutan para tenaga kerja termasuk satpam, yakni "tolak upah murah", dan tidak terdapat aturan yang dibuat oleh pemerintah atau peraturan yang lainnya yang melakukan pengaturan terhadap gaji yang diterima oleh para satpam.

Sehingga dari itu saat ini aturan undang-undang yang didalamnya memberikan pengaturan mengenai tenaga kerja Satpam hanya diatur didalam perundang-undangan tentang tenaga kerja No 13 Tahun 2003 serta aturan Pemerintah Nomor 35 Tahun 2021. Untuk itu perlunya suatu regulasi yang relevan untuk mengatur sistem pengupahan minimun yang sebanding dengan tugas dan risiko dalam penugasan Satpam sesuai dengan Masa Kerja, Kualifikasi, Kompetensi, Sertifikasi, dan Jabatan.

Dalam upaya Satuan Pengamanan menjadi Profesi yang bermartabat di negara ini akan bisa diwujudkan jika mempunyai landasan hukum yang dan mencukupi, sebab kepastian hukum serta perlindungan hukum para pekerja satuan pengaman bisa diakomodir dengan maksimal. Diharapkan regulasinya tidak hanya aturan yang dibuat oleh Kapolri namun juga dengan perundang-undangan satpam yang sesuai.

\footnotetext{
${ }^{25}$ Upah, K. P. (1970). Konvensi Penetapan Upah Minimum, 1970

${ }^{26}$ Wijayanti, A. (2012). Menuju Sistem Hukum Perburuhan Indonesia Yang Berkeadilan. Arena Hukum, 5(3), 210-217. https://doi.org/10.21776/ub.arenahukum.2012.00503.7
} 


\section{Simpulan.}

Status Ketenagakerjaan dari Satuan Pengamanan diatur dalam Undang-Undang Nomor 13 Tahun 2003 tentang Ketenagakerjaan serta Peraturan Pemerintah Nomor 35 tahun 2021 yang didalamnya menjelaskan mengenai PKWT "Perjanjian Kerja Waktu Tertentu", alih daya, waktu dalam beristirahat, waktu dalam melakukan pekerjaan serta tindakan memutus hubungan kerja.

Penyebutan kata Profesi yang tertuang di dalam Perpol Nomor 4 Tentang Pengamanan Swakarsa, dalam penjabaran pekerjaan Satpam sudah semestinya dilakukan, dikarenakan Satpam merupakan sebuah profesi yang mempunyai fungsi kepolisian terbatas dilingkungan kerjanya dan sudah memenuhi syarat sebuah profesi. Pada saat ini satpam sudah menjadi Suatu profesi, Oleh karena itu bisa dilaksanakan sebagai langkah yang diintegrasikan antara Polri, Asosiasi Satpam serta pihak yang mempunyai kepentingan untuk melakukan sinergi dalam menghasilkan Satpam yang mempunyai martabat dan professional.

Peraturan Kepolisian Nomor 4 Tentang Pengamanan Swakarsa tidak sepenuhnya bisa mewujudkan pemuliaan profesi Satpam. Karena, kesenjangan Satpam juga perlu di benahi terutama tentang Standar Skala Upah yang diterima dengan mempertimbangkan profesi Satpam mempunyai risiko yang tinggi dan bahkan aset pengguna jasa tenaga Satpam ada di tangan anggota Satpam. Oleh karena itu, perlu adanya suatu regulasi yang relevan dari Kapolri, Pemerintah dalam hal ini Kementerian Ketenagakerjaan, para Asosiasi Satpam, dan Instansi/Lembaga pemangku terkait, untuk mengatur sistem pengupahan minimun yang sebanding dengan tugas dan risiko dalam penugasan Satpam sesuai dengan Masa Kerja, Kualifikasi, Kompetensi, Sertifikasi, dan Kepangkatan.

\section{Daftar Pusaka}

\section{Buku}

G.Kartasapoetra, R.G.Kartasapoetra, 1986, hukum Ketenagakerjaan di Indonesia sesuai dengan Pancasila,Cetakan ke 1, Bina Aksara, Yogyakarta, hal. 20

H. Arkian Luis, 2019, Satpam Indonesia, Jakarta, Elex Media Komputindo.

Polda Metro Jaya, 2016, pengantar satuan keamanan, Jakarta, PT.Universal Security Indonesia.

Sutedi, Heru. (2012), Kontroversi pekerja serta pihak pengusaha, Jakarta, HS Publising

Wijayanti, Asri. (2009), hukum tenaga kerja setelah masa reformasi, Jakarta, Sinar Grafika

Wijayanti, A. (2011), hak serikat buruh di negara Indonesia, Disertasi, PPS Universitas Airlangga, hal. 18

\section{Jurnal}

Achmad Hariri, Rekontruksi Pancasila Sebagai Ideologi Selaku Sistem Ekonomi Pada Perspektif Welfare State, Jurnal Hukum Replik, Vol. 7 No.1, Maret 2019.

Aksin N, (2018), Upah Dan Tenaga Kerja (Hukum Ketenagakerjaan Dalam Islam), Jurnal Meta-Yuridis, Vol 1.No 2.

P.Murung, K., \& Buhoy,(2013). Perlindungan Hukum Bagi Pekerja ( Hambatan dan Upaya Sistem Perjanjian Kerja Waktu Tertentu. 308-335. Arena Hukum, Vol 6, No 3. 
Irawan, A. D., Samudra, K. P., \& Pratama, A. (2021). Perlindungan Hak Asasi Manusia oleh Pemerintah pada Masa Pandemi COVID-19. Jurnal Citizenship Virtues, 1(1), 1-6. https://doi.org/10.37640/jcv.v1i1.902

Irawan, A. D., (2019) Status Hukum Outsourcing Pasca Putusan Mahkamah Konstitusi Perkara Nomor 27/PUU-IX/2011, Arena Hukum, Vol.12, No 2.

Nursalim, C. R. P., \& Suryono, L. J. (2021). Perlindungan Hukum Tenaga Kerja pada Perjanjian Kerja Outsourcing. Media of Law and Sharia, 2(1), 47-62. https://doi.org/10.18196/mls.v2i1.11478

Wijayanti, A. (2012). Menuju Sistem Hukum Perburuhan Indonesia Yang Berkeadilan. Arena Hukum, 5(3), 210-217. https://doi.org/10.21776/ub.arenahukum.2012.00503.7

Wijayanti, A, (2017) Rights to the freedom of trade unions in the constitution and its implementastion, International journal off Applied Business in Economic Research Vol. 15, No.7.

Wijayanti, A. Recognition And Protection of Religious Sects In Indonesia, Man in India, http://serialsjournals.com/serialjournalmanager/pdf/1507180504.pdf

Wijayanti, A. (2012). Sistem Hukum Ketenagakerjaan Indonesia Yang Sesuai Dengan Keadilan. Arena Hukum, 5(3), 210-217. https://doi.org/10.21776/ub.arenahukum.2012.00503.7

\section{Regulasi}

Undang-Undang Nomor 11 Tahun 2020 Cipta Kerja

Undang-undang Nomor 13 Tahun 2003 Tentang Ketenagakerjaan

Undang-undang Nomor 2 Tahun 2002 Tentang Kepolisian Republik Indonesia

Peraturan Pemerintah Nomor 35 Tahun 2021 Tentang Perjanjian Kerja Waktu Tertentu (PKWT), Alih Daya, Waktu Kerja dan Waktu Istirahat, dan Pemutusan Hubungan Kerja.

Peraturan Kepala Kepolisian Negara Republik Indonesia Nomor 24 Tahun 2007 tentang Sistem Manajemen Pengamanan Organisasi, Perusahaan dan/atau Instansi/lembaga Pemerintah.

Peraturan Kepolisian Republik Indonesia Nomor 4 Tahun 2020 Tentang Pengamanan Swakarsa. 